\section{Response of Young Pecan Trees to Repeated Applications of Indaziflam and Halosulfuron}

\author{
Timothy L. Grey ${ }^{1,5}$ \\ Department of Crop and Soil Sciences, University of Georgia, Tifton \\ Campus, 2360 Rainwater Road, Tifton, GA 31793
}

Keith Rucker ${ }^{2}$
Bayer Crop Science, Tifton, GA 31794

Lenny Wells ${ }^{3}$

Department of Horticulture, University of Georgia, Tifton Campus, 2360 Rainwater Road, Tifton, GA 31793

\section{Xuelin $\mathbf{L u o}^{4}$ \\ Experimental Statistics, University of Georgia, Tifton Campus, 2360 Rainwater Road, Tifton, GA 31793}

Additional index words. halosulfuron, indaziflam, pecan, Carya illinoinensis (Wangenh.) K. Koch, soil residual herbicides

\begin{abstract}
Pecan production in the southeastern United States has increased because of the worldwide demand for the nuts of this tree. Information about the effects of the residual herbicides indaziflam and halosulfuron on newly planted pecan trees was evaluated over time for 4 years on sandy loam soils. After winter pecan tree planting, multiple spring or autumn herbicide applications were applied to the same pecan trees in different experiments in consecutive years. Visual injury, height, and caliper diameter measurements were taken up to six times during the growing season. Regression analysis of treatments over time indicated no differences in pecan tree growth for indaziflam at 73 or $146 \mathrm{~g} \mathrm{a.i./ha}$ or halosulfuron at $35 \mathrm{~g}$ a.i./ha applied up to six times in 3 years, or for indaziflam at 37, 73, or $146 \mathrm{~g}$ a.i./ha applied up to five times in 3 years, as compared with nontreated controls. This information will benefit growers seeking viable weed control options when establishing new groves to meet the increased worldwide demand for pecan nuts.
\end{abstract}

Pecan production is increasing in the United States as exports to foreign markets have stimulated value and prompted newly planted groves (Wells, 2014). Between 2009 and 2014, the U.S. in-shell pecan production (nuts from improved, native, and seedling trees) averaged more than $181,400 \mathrm{t}$ each year, valued at more than $\$ 479$ million (NASS, 2015). In the United States, Georgia consistently ranks number one in pecan production generating $36,000 \mathrm{t}$ on $63,464 \mathrm{ha}$, with a value of $\$ 361$ million in 2015 (Wolfe

Received for publication 9 Oct. 2017. Accepted for publication 20 Jan. 2018.

This research was partially funded by the University of Georgia College of Agriculture and Bayer Crop Science. Technical support was provided by Sidney Cromer, Fritz Turpin, II, Haydon Davis, and additional statistical support from Jerry Davis, all with the University of Georgia.

We would like to thank Mitch Bolger of Pine Knoll Plantation and Richard Merritt of Merritt Pecan Company for providing materials for this research trial.

${ }^{1}$ Professor

${ }^{2}$ Technical Service Specialist.

${ }^{3}$ Associate Professor.

${ }^{4}$ Research Professional.

${ }^{5}$ Corresponding author. E-mail: tgrey@uga.edu. and Stubbs, 2016). With increased demand and value, growers in Georgia have begun to interplant older groves with new cultivars (Wells, 2014). This can expose newly planted trees to herbicides that have been applied in previous seasons and are presently labeled for bearing crops. In addition, greater than 6000 ha of new groves were planted from 2010 to 2014, to more than 391,000 trees in Georgia (Wells, 2014). It is forecast that production in Georgia could exceed $121,000 \mathrm{t}$ annually by 2025 with newly planted trees and renovated groves.

Pecan trees in commercial production are often irrigated with solid set risers or emitters near each tree (Wells, 2015). Nearly all commercial groves are irrigated, although exact data from Georgia are not available. Although irrigation is necessary for maximum yields, it also can promote growth of weeds (Faircloth et al., 2007). Weed competition can reduce growth in pecan groves by more than $50 \%$. Newly planted trees are especially sensitive to competition for sunlight, moisture, and nutrients (Smith, 2011). In established groves, weeds also serve as inoculum for diseases and alternate hosts for insects (Lee, 1994). Establishing a weed-free strip by applying herbicides between pecan trees to increase survival, water use efficiency, and growth is a common practice (Faircloth et al., 2007). This reduces the time required for pecan trees to begin bearing nuts and producing the first commercially viable yield (Smith, 2011).

Indaziflam is an alkylazine herbicide assigned to group 29 by the Weed Science Society of America (Shaner, 2014). It is an effective soil residual herbicide registered for citrus (Citrus L.), apple (Malus Mill.), pear (Pyrus L.), stone (Prunus L.) and pome (Punica L.) fruits, grape (Vitis L.), olive (Olea europaea L. ssp. europaea), and tree nuts. Indaziflam is classified as a cellulose biosynthesis inhibitor (Brabham et al., 2014) with no reports of any resistant weeds (Brabham et al., 2014; Shaner, 2014).

Indaziflam's soil persistence has reported half-lives of $>150 \mathrm{~d}$ (U.S. EPA, 2010), with others indicating 22-176 d (GonzálezDelgado et al., 2015). The water solubility of indaziflam increases with increasing $\mathrm{pH}$ from $2.0 \mathrm{~g} \cdot \mathrm{L}^{-1}$ at $\mathrm{pH} 7$ to $18.3 \mathrm{~g} \cdot \mathrm{L}^{-1}$ at $\mathrm{pH} 9$ (Shaner, 2014). Using Italian ryegrass [Lolium perenne L. subsp. multiflorum (Lam.) Husnot] as a bioassay indicator, Jhala et al. (2012) determined that indaziflam did not leach beyond $30 \mathrm{~cm}$ deep in sand soil, when evaluated in column studies. Indaziflam desorption was hysteric for multiple soils examined, indicating decreased potential for mobility (Alonso et al., 2015). Turf weed control with indaziflam was noted for up to 28 weeks (McCullough et al., 2013; Perry et al., 2011) and at least 6 months of weed control noted in pistachio (Pistacia vera $\mathrm{L}$.), pome fruit, stone fruit, and citrus (Allen, 2011). For Florida citrus, indaziflam has a 24(c) supplemental label for potted trees planted for a minimum of 1 year (Anonymous, 2015a; Jhala et al., 2013). Total seasonal rates for perennial crops can range from 50 to $150 \mathrm{~g}$ a.i./ha.

Halosulfuron is also registered to control perennial nutsedges and broadleaf weeds in perennial crops including pecan, with total seasonal use rates of $35-70 \mathrm{~g}$ a.i./ha (Anonymous, 2015b). Halosulfuron has multiple registrations, including perennial crops. Soil longevity of halosulfuron varies with adsorption to soil colloids and soil organic carbon, with availability often inversely related to soil $\mathrm{pH}$ (Dermiyati and Yamamoto, 1997a). Degradation can increase with increasing soil temperature and lower soil pHs, with soil moisture content and soil type further affecting carryover (Dermiyati and Yamamoto, 1997b). Dissipation is primarily by chemical hydrolysis and microbial degradation and is much faster in acid and basic solutions and slower under neutral conditions (Zheng et al., 2008). Halosulfuron half-life ranges from 6 to $98 \mathrm{~d}$, depending on soil moisture and temperature regimes (Dermiyati and Yamamoto, 1997b; Grey et al., 2007a) and can exhibit hysteric effects (Carpenter et al., 1999). Injury from halosulfuron carryover to rotational crops has occurred as a result of its variable soil behavior (Grey et al., 2007b). Although halosulfuron has been extensively evaluated in annual crops for tolerance and carryover (Dittmar et al., 2008; Haar 
Table 1. Test information for evaluation of herbicides in pecan trees in Dougherty and Webster Counties, GA, $2011-14$.

\begin{tabular}{|c|c|c|c|c|c|c|c|c|c|c|}
\hline \multirow[b]{2}{*}{ Location } & \multicolumn{2}{|c|}{ Planting information } & \multicolumn{2}{|c|}{$2011^{z}$} & \multicolumn{2}{|c|}{$2012^{z}$} & \multicolumn{2}{|c|}{$2013^{z}$} & \multicolumn{2}{|c|}{$2014^{z}$} \\
\hline & Cultivar & Date & First & Second & First & Second & First & Second & First & Second \\
\hline Dougherty Test 1 & Byrd & Jan. 2011 & 15 Mar. & 15 Apr. & 2 Apr. & 10 May & 29 Mar. & 14 May & - & - \\
\hline Dougherty Test 2 & Pawnee & Jan. 2012 & - & - & 2 Apr. & 10 May & 29 Mar. & 14 May & 14 Mar. & 17 Apr. \\
\hline Dougherty Test 3 & Pawnee & Jan. 2012 & - & - & 4 Apr. & 13 Sept. & 29 Mar. & 13 Sept. & 14 Mar. & - \\
\hline Webster Test 4 & Pawnee & Feb. 2012 & - & - & 26 Mar. & 13 Sept. & 29 Mar. & 19 Sept. & 14 Mar. & - \\
\hline
\end{tabular}

${ }^{\mathrm{z}}$ Herbicide application timing for that research test location and year.

Table 2. Average monthly rainfall, solar radiation, and growing-degree-day accumulation from the University of Georgia weather station 1 km from experiments ${ }^{2}$ in Dougherty County, GA.

\begin{tabular}{|c|c|c|c|c|c|c|c|c|c|c|c|c|}
\hline \multirow[b]{2}{*}{ Month } & \multicolumn{3}{|c|}{2011} & \multicolumn{3}{|c|}{2012} & \multicolumn{3}{|c|}{2013} & \multicolumn{3}{|c|}{2014} \\
\hline & $\mathrm{R}(\mathrm{mm})$ & $\mathrm{SR}\left(\mathrm{MJ} \cdot \mathrm{m}^{-1}\right)$ & GDD & $\mathrm{R}(\mathrm{mm})$ & $\mathrm{SR}\left(\mathrm{MJ} \cdot \mathrm{m}^{-1}\right)$ & GDD & $\mathrm{R}(\mathrm{mm})$ & $\mathrm{SR}\left(\mathrm{MJ} \cdot \mathrm{m}^{-1}\right)$ & GDD & $\mathrm{R}(\mathrm{mm})$ & $\mathrm{SR}\left(\mathrm{MJ} \cdot \mathrm{m}^{-1}\right)$ & GDD \\
\hline January & - & - & - & 71 & 340 & - & 42 & 294 & - & 72 & 345 & - \\
\hline February & - & - & - & 90 & 280 & - & 348 & 299 & - & 133 & 355 & - \\
\hline March & 42 & 243 & 54 & 123 & 488 & 112 & 106 & 546 & - & 134 & 526 & - \\
\hline April & 44 & 675 & 152 & 56 & 612 & 120 & 87 & 533 & 80 & 294 & 533 & 85 \\
\hline May & 17 & 774 & 246 & 81 & 650 & 260 & 46 & 655 & 186 & 96 & 727 & 225 \\
\hline June & 73 & 752 & 396 & 65 & 617 & 282 & 234 & 633 & 338 & 119 & 716 & 332 \\
\hline July & 166 & 649 & 400 & 93 & 619 & 391 & 205 & 526 & 339 & 122 & 679 & 351 \\
\hline August & 81 & 656 & 411 & 91 & 482 & 333 & 237 & 529 & 342 & 41 & 632 & 374 \\
\hline September & 40 & 484 & 214 & 126 & 503 & 259 & 92 & 471 & 277 & 152 & 468 & 297 \\
\hline October & 65 & 461 & 59 & 10 & 408 & 115 & 13 & 441 & 127 & 75 & 507 & 123 \\
\hline November & 15 & 359 & - & 22 & 341 & - & 69 & 344 & - & 100 & 358 & \\
\hline December & 64 & 290 & - & 90 & 262 & - & 135 & 263 & - & 162 & 274 & \\
\hline
\end{tabular}

${ }^{\mathrm{z}} \mathrm{R}, \mathrm{SR}$, and GDDs are reported from initial herbicide application date for T1, T2, and T3.

$\mathrm{R}=$ rainfall; $\mathrm{SR}=$ solar radiation; $\mathrm{GDD}=$ growing degree day; $\mathrm{T} 1, \mathrm{~T} 2$, and $\mathrm{T} 3=$ Dougherty Tests 1,2 , and 3 .

et al., 2002; Jennings, 2010; Sikkema et al., 2008; Webster et al., 2003), little information about pecan tree tolerance has been reported.

As a nonselective cellulose biosynthesis inhibitor, having low soil mobility, along with a long soil half-life, indaziflam has a niche for broad-spectrum control of annual grasses and broadleaf weeds in pecan groves for maintaining bare ground in the tree row. The sulfonylurea residual herbicide halosulfuron provides excellent control of nutsedge and broadleaf weed species and could be used to assist in maintaining a weed-free environment, especially in irrigated groves where these weed species can proliferate. Although pecan production in Georgia continues to increase in hectares and value, limited information about these herbicides' effects on newly planted trees in newly planted or established groves settings is available. Therefore, the objective of this research was to determine the effects on in-field establishment and growth of pecan trees with multiple applications of indaziflam and halosulfuron over time.

\section{Materials and Methods}

Experiments were conducted at two locations in Georgia. Location one had three experiments from 2011 to 2014 in different areas of the same field at Pine Knoll Plantation near Ducker in Dougherty County. Dougherty Test 1 (T1) was conducted from 2011 to 2013 and was located at $31.528^{\circ} \mathrm{N}$, $-84.3665^{\circ} \mathrm{W}$. Dougherty Tests 2 and 3 (T2 and T3) were conducted from 2012 to 2014 at $31.541^{\circ} \mathrm{N},-84.3688^{\circ} \mathrm{W}$. Location two had one experiment from 2012 to 2014 near Weston in Webster County (T4) at $31.984^{\circ} \mathrm{N}$, $-84.616^{\circ} \mathrm{W}$. Soil types were Greenville sandy clay loam (fine, kaolinitic, and thermic Rhodic

Table 3. Average monthly rainfall, solar radiation, and growing degree day from the University of Georgia weather station $20 \mathrm{~km}$ from experiments $\mathrm{s}^{\mathrm{z}}$ in Webster County, GA.

\begin{tabular}{|c|c|c|c|c|c|c|c|c|c|}
\hline \multirow[b]{2}{*}{ Month } & \multicolumn{3}{|c|}{2012} & \multicolumn{3}{|c|}{2013} & \multicolumn{3}{|c|}{2014} \\
\hline & $\mathrm{R}(\mathrm{mm})$ & $\mathrm{SR}\left(\mathrm{MJ} \cdot \mathrm{m}^{-1}\right)$ & GDD & $\mathrm{R}(\mathrm{mm})$ & SR $\left(\mathrm{MJ} \cdot \mathrm{m}^{-1}\right)$ & GDD & $\bar{R}(\mathrm{~mm})$ & SR $\left(\mathrm{MJ} \cdot \mathrm{m}^{-1}\right)$ & GDD \\
\hline January & - & - & - & 23 & 294 & - & 79 & 324 & - \\
\hline February & - & - & - & 252 & 341 & - & 105 & 329 & - \\
\hline March & 26 & 118 & - & 124 & 579 & - & 86 & 484 & - \\
\hline April & 38 & 681 & 117 & 79 & 602 & 80 & 201 & 530 & 82 \\
\hline May & 29 & 730 & 228 & 57 & 702 & 179 & 34 & 730 & 227 \\
\hline June & 78 & 674 & 294 & 135 & 619 & 311 & 47 & 661 & 343 \\
\hline July & 94 & 695 & 393 & 195 & 556 & 321 & 68 & 674 & 357 \\
\hline August & 46 & 563 & 339 & 150 & 587 & 335 & 25 & 629 & 368 \\
\hline September & 114 & 545 & 262 & 55 & 525 & 271 & 76 & 429 & 292 \\
\hline October & 1 & 480 & 123 & 35 & 464 & 129 & 64 & 473 & 131 \\
\hline November & 25 & 375 & - & 38 & 335 & - & 109 & 349 & - \\
\hline December & 121 & 260 & - & 220 & 226 & - & 131 & 259 & - \\
\hline
\end{tabular}

${ }^{\mathrm{z}} \mathrm{R}$, SR, and GDDs are reported from initial herbicide application date for T4.

$\mathrm{R}=$ rainfall; $\mathrm{SR}=$ solar radiation; $\mathrm{GDD}=$ growing degree day; $\mathrm{T} 4$ = Dougherty Test 4.

Table 4. Parameter estimates of linear regression of pecan tree trunk growth regressed on growing degree days (GDDs) for newly planted trees ${ }^{\mathrm{z}}$ in Dougherty County, GA (equation: $y=a+b x$ ).

\begin{tabular}{|c|c|c|c|c|c|c|c|c|}
\hline & \multicolumn{2}{|c|}{ Timing $^{y}$} & \multicolumn{3}{|c|}{ Dougherty County Test 1} & \multicolumn{3}{|c|}{ Dougherty County Test 2} \\
\hline & $\begin{array}{c}\text { First } \\
\text { (g a.i./ha) }\end{array}$ & $\begin{array}{c}\text { Second } \\
\text { (g a.i./ha) }\end{array}$ & $\begin{array}{c}a^{\mathrm{x}} \\
(\mathrm{mm})\end{array}$ & $\begin{array}{c}b^{\mathrm{x}} \\
(\mathrm{mm} / \mathrm{GDD})\end{array}$ & $r^{2}$ & $\begin{array}{c}a^{\mathrm{x}} \\
(\mathrm{mm})\end{array}$ & $\begin{array}{c}b^{\mathrm{x}} \\
(\mathrm{mm} / \mathrm{GDD})\end{array}$ & $r^{2}$ \\
\hline Nontreated $^{\mathrm{w}}$ & - & - & 21.1 & $0.0122 \mathrm{a}^{\mathrm{v}}$ & 0.93 & 13.8 & $0.0070 \mathrm{c}^{\mathrm{v}}$ & 0.95 \\
\hline & 73 & 73 & & & 0. & 14 & $4 \mathrm{ab}$ & 0.93 \\
\hline Indaz & 146 & 146 & 21.8 & $0.0115 \mathrm{ab}$ & 0.94 & 14.1 & $0.0086 \mathrm{a}$ & 0.96 \\
\hline Halosulfuron & 35 & 35 & 22.8 & $0.0111 \mathrm{~b}$ & 0.93 & 14.8 & $0.0075 \mathrm{bc}$ & 0.93 \\
\hline
\end{tabular}

${ }^{\mathrm{z}}$ At the time of first applications in 2011 and 2012, pecan trees had been planted for 3 months.

${ }^{\mathrm{y}}$ See Table 1 for application dates. For all treatments, Tests 1 and 2 received six applications in total over time.

${ }^{\mathrm{x}}$ Differences in slopes among the herbicide treatments based on REG procedure using test slope in SAS/ STAT $^{\circledR} 9.2$ User's Guide, second edition (SAS Institute).

${ }^{\mathrm{w}}$ Nontreated: indicates no residual herbicide. Plots maintained weed free by the contact herbicide glufosinate during test.

${ }^{\mathrm{v}}$ Values for growth rate by GDD within a column followed by the same letter are not significantly different at $P<0.05 P$ level.

Kandiudults) with $64 \%$ sand, $12 \%$ silt, $24 \%$ clay, and $0.5 \%$ to $1.0 \%$ organic matter, with $\mathrm{pHs}$ from 6.1 to 6.5 for $\mathrm{T} 1, \mathrm{~T} 2$, and $\mathrm{T} 3$ in Dougherty County. The soil type was Faceville loamy sand (fine, kaolinitic, and thermic Typic Kandiudults) with $80 \%$ sand, $10 \%$ silt, $10 \%$ clay, and $1.4 \%$ organic matter, with $\mathrm{pH}$ of 6.0 for T4 in Webster County. 
Pecan tree planting date, cultivars, and treatment application information are in Table 1. For Dougherty T1, T2, and T3, pecan trees were planted in rows spaced $12.2 \mathrm{~m}$ wide, with an in-row spacing of $6.1 \mathrm{~m}$. For Webster T4, trees were planted in rows spaced $12.2 \mathrm{~m}$ wide, with an in-row spacing of $7.6 \mathrm{~m}$. Subsoil irrigation tubes were installed with emitters soon after planting before treatment for all tests; these provided water and fertilizers per recommendations from the grower. All maintenance practices for disease control and cultural considerations were common to all trees during the growing seasons for all experiments and directed by the growers, and maintained weed free by applications of glufosinate. All trials were randomized complete block designs with four replications per treatment. Herbicides were applied to a weed-free soil surface using compressed air, calibrated to deliver $140 \mathrm{~L} \cdot \mathrm{ha}^{-1}$ to either side of the tree row with a four-nozzle $1.8-\mathrm{m}$ tractor-mounted boom. Test and treatment timing information is outlined for each test in Table 1. After winter pecan tree planting, repeated spring or autumn herbicide applications were applied to the same pecan trees in different experiments in consecutive years. Dougherty T1 and T2 (duplicated tests) received six applications over 26 months, with Dougherty T3 and Webster T4 (duplicated tests) receiving five treatments in 24 months. All experiments were ended with the final measurement in Oct. 2014.

Stem diameter was determined using caliper measures taken $25 \mathrm{~cm}$ above the soil line on the main trunk, always above the graft. Diameter measures were taken 5-8 times during the growing season each year. A single plot consisted of either four or five trees, and all trees were measured for all data collection timings. Height measures from the soil to the apex of each tree were taken at least 5 times in the first year for each experiment, before pruning in the second year. No height measures were taken in the second or third years of each experiment. Visual estimates of injury were determined based on a combination of plant chlorosis and necrosis, or plant stunting, with a scale of $0 \%$ (no injury relative to the plots not treated with a residual herbicide) to $100 \%$ (plant death). Crop injury was evaluated multiple times each year throughout each experiment.

Average rainfall, solar radiation, and temperature data used for growing-degree-day (GDD) calculation were collected at Georgia Weather Monitoring Network stations, located within $1 \mathrm{~km}$ of experiments $\mathrm{T} 1, \mathrm{~T} 2$, and T3 in Dougherty County and $20 \mathrm{~km}$ (Plains) of T4 in Webster County (Flitcroft, 2015). GDDs were calculated by using daily minimum and maximum air temperature for the months when actively growing trees had leaves. For the GDD accumulation equation,

$$
t_{n}=\sum_{i=1}^{n}\left[\frac{T i_{\max }+T i_{\min }}{2}-T_{b}\right]
$$

$t_{n}$ is the sum of GDDs for $n$ days, and $T i_{\max }$ and $T i_{\min }$ are the daily maximum and minimum temperature $C$ of day $i$. Previous studies used a base temperature of $15.5^{\circ} \mathrm{C}$ for the pecan tree (Andales et al., 2006). By using GDDs,

a more biologically meaningful measure of tree growth can be established rather than just comparing time after planting.

Table 5. Parameter estimates of linear regression of pecan tree trunk growth regressed on growing degree days (GDDs) for newly planted trees ${ }^{\mathrm{z}}$ in Dougherty and Webster Counties, GA (equation: $y=a+b x$ ).

\begin{tabular}{|c|c|c|c|c|c|c|c|c|}
\hline & \multicolumn{2}{|c|}{ Timing $^{y}$} & \multicolumn{3}{|c|}{ Dougherty County Test 3} & \multicolumn{3}{|c|}{ Webster County Test 4} \\
\hline & $\overline{\text { First (g a.i./ha) }}$ & Second (g a.i./ha) & $\overline{a^{\mathrm{x}}(\mathrm{mm})}$ & $b^{\mathrm{x}}(\mathrm{mm} / \mathrm{GDD})$ & $r^{2}$ & $\overline{a^{\mathrm{x}}(\mathrm{mm})}$ & $b^{\mathrm{x}}(\mathrm{mm} / \mathrm{GDD})$ & $r^{2}$ \\
\hline & - & - & 15.8 & $0.0070 \mathrm{c}^{\mathrm{v}}$ & 0.89 & 12.1 & $0.0097 \mathrm{a}^{\mathrm{v}}$ & $\overline{0.9}$ \\
\hline & 37 & 37 & 13.7 & & 0.91 & 11.1 & & \\
\hline & 73 & 73 & 13.0 & $0.0087 \mathrm{ab}$ & 0.94 & 12.0 & $0.0100 \mathrm{a}$ & \\
\hline Indaziflam & 146 & 146 & 14.0 & $0.0093 \mathrm{a}$ & 0.92 & 12.6 & $0.0092 \mathrm{a}$ & 0.8 \\
\hline
\end{tabular}

${ }^{\mathrm{z}}$ At the time of first applications in 2012, pecan trees had been planted for 3 months.

${ }^{\mathrm{y}}$ See Table 1 for application dates. For all treatments, Tests 3 and 4 received five applications in total over time.

${ }^{\mathrm{x}}$ Differences in slopes among the herbicide treatments based on REG procedure using test slope in SAS/ STAT $^{\circledR} 9.2$ User's Guide, second edition (SAS Institute).

${ }^{\text {w}}$ Nontreated: indicates no residual herbicide. Plots maintained weed free by the contact herbicide glufosinate during test.

${ }^{v}$ Values for growth rate by GDDs within a column followed by the same letter are not significantly different at $P<0.05 P$ level.

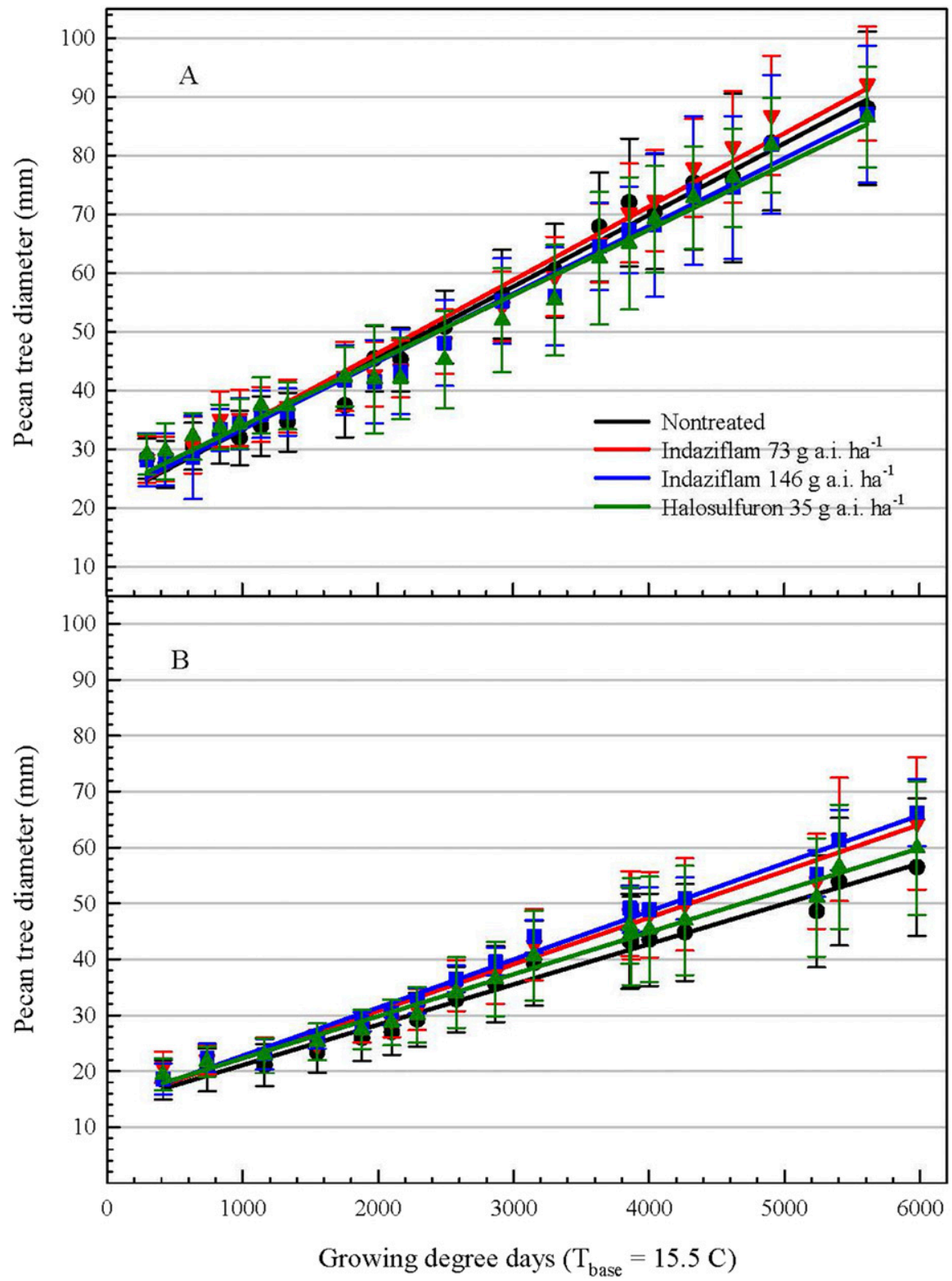

Fig. 1. Pecan tree growth response to multiple spring applications of indaziflam and halosulfuron over growing degree days from 2011 to 2013 (A) and 2012-14 (B) in Dougherty County, GA. Herbicide application dates are in Table 1 and parameter estimates for linear regression equations are in Table 4. 
As each experiment was conducted on different trees with different planting dates with multiple measures over time, and at different locations, data for each experiment were analyzed separately. All data were subjected to analysis of variance using the PROC MIXED procedure to test for interactions between treatments for leaf chlorosis, necrosis, and height measures. Linear regression analysis with the equation

$$
y=a+b x
$$

was used to model growth, where $a$ is the $y$-intercept and $b$ is the average tree growth by degree growing day. Differences in parameter estimates for the slopes among the herbicide treatments for tree growth (Glantz and Slinker, 2001) were conducted using the REG procedure in SAS/STAT ${ }^{\circledR} 9.2$ (SAS Institute, Raleigh, NC) (SAS Institute Inc., 2012).

\section{Results and Discussion}

There were differences for environmental measures taken during the course of each experiment for rainfall, solar radiation, and GDDs (Tables 2 and 3). However, all experiments were conducted at times when herbicide applications could potentially occur in Georgia pecan production and are thus representative of producer practices.

Pecan tree cultivars Byrd and Pawnee exhibited no visual injury symptoms in the form of leaf chlorosis or necrosis to indaziflam and halosulfuron as compared with the nontreated controls (data not shown). Multivariate analysis of variance indicated that there were no differences in tree height or visual injury symptoms for all rates of indaziflam and halosulfuron as compared with the nontreated control for any of the studies (data not shown). González-Delgado et al. (2017) noted no phytotoxicity effects on greenhouse-grown trees subjected to rates of 50-150 g a.i./ha.

Tree diameter in terms of the $y$-intercept at the beginning of each test varied by location and year ranging from 11.1 to $22.8 \mathrm{~mm}$ for the $a$ parameter (Tables 4 and 5). However, trees within each experiment had little variation with less than $2.1 \mathrm{~mm}$ diameter differences for the $a$ parameter estimates across all tests. Linear regression indicated good fit of results with $r^{2}$ of $0.82-0.96$.

Caliper diameter measure data regressed over GDDs indicated that indaziflam applied multiple times in the spring of each year did not negatively affect pecan tree growth (Table 4; Fig. 1). For the Dougherty T1 experiment, 'Byrd' pecan trees that had indaziflam applied at 73 or $146 \mathrm{~g}$ a.i./ha six times over 31 months exhibited growth equal to the nontreated control with parameter estimates of $b$ at $0.0124,0.0115$, and $0.0122 \mathrm{~mm} / \mathrm{GDD}$, respectively (Table 4; Fig. 1A). For Dougherty T2, 'Pawnee' pecan trees treated with indaziflam at these same rates had significantly greater rate of growth than that of the nontreated control with parameter estimates of 0.0084 and 0.0086 vs. $0.007 \mathrm{~mm} / \mathrm{GDD}$, respectively (Table 4 ; Fig. 1B). Halosulfuron-treated tree growth was significantly less than that of the nontreated control in Dougherty T1 and did not differ for Dougherty T2. With additional indaziflam and halosulfuron applications each year, the rate of pecan tree stem diameter consistently increased over time. By the final measures taken in October of 2013 and 2014, the total applications of indaziflam amounted to 438 and $876 \mathrm{~g}$ a.i./ha, and halosulfuron at $210 \mathrm{~g}$ a.i./ha cumulatively over 31 months in Dougherty County T1 and T2.

For Dougherty T3, 'Pawnee' pecan tree trunk growth response to spring and autumn applications of indaziflam at 37, 73, and 146 $\mathrm{g}$ a.i./ha was significantly greater than that of the nontreated control, with $b$ parameter estimates of $0.0082,0.0087,0.0093$, and 0.007 $\mathrm{mm} / \mathrm{GDD}$, respectively (Table 5; Fig. 2A). All plots were maintained weed free for the entire course of this research, so no reason can be given as to why tree growth was greater for the indaziflam treatments. Conversely, for Webster T4 for the same treatments, there was no difference in tree growth (Table 5; Fig. 2B). With five total applications from 2012 to 2014 (Table 1), total indaziflam amounted to 185,365 , and $730 \mathrm{~g}$ a.i./ha over the course of these experiments in 31 months. All pecan tree stem diameter increased each year, with no treatment differences.

Injury to pecan trees from indaziflam has been reported in Arizona and New Mexico, and attributed to production practices (flood irrigation), the increased availability of indaziflam at soil $\mathrm{pH}$ of 8.49 (González-Delgado et al., 2015), and leaching and concentrating indaziflam into the tree root zone (Jhala et al., 2012). Also, indaziflam desorption was hysteric for multiple soils examined, indicating

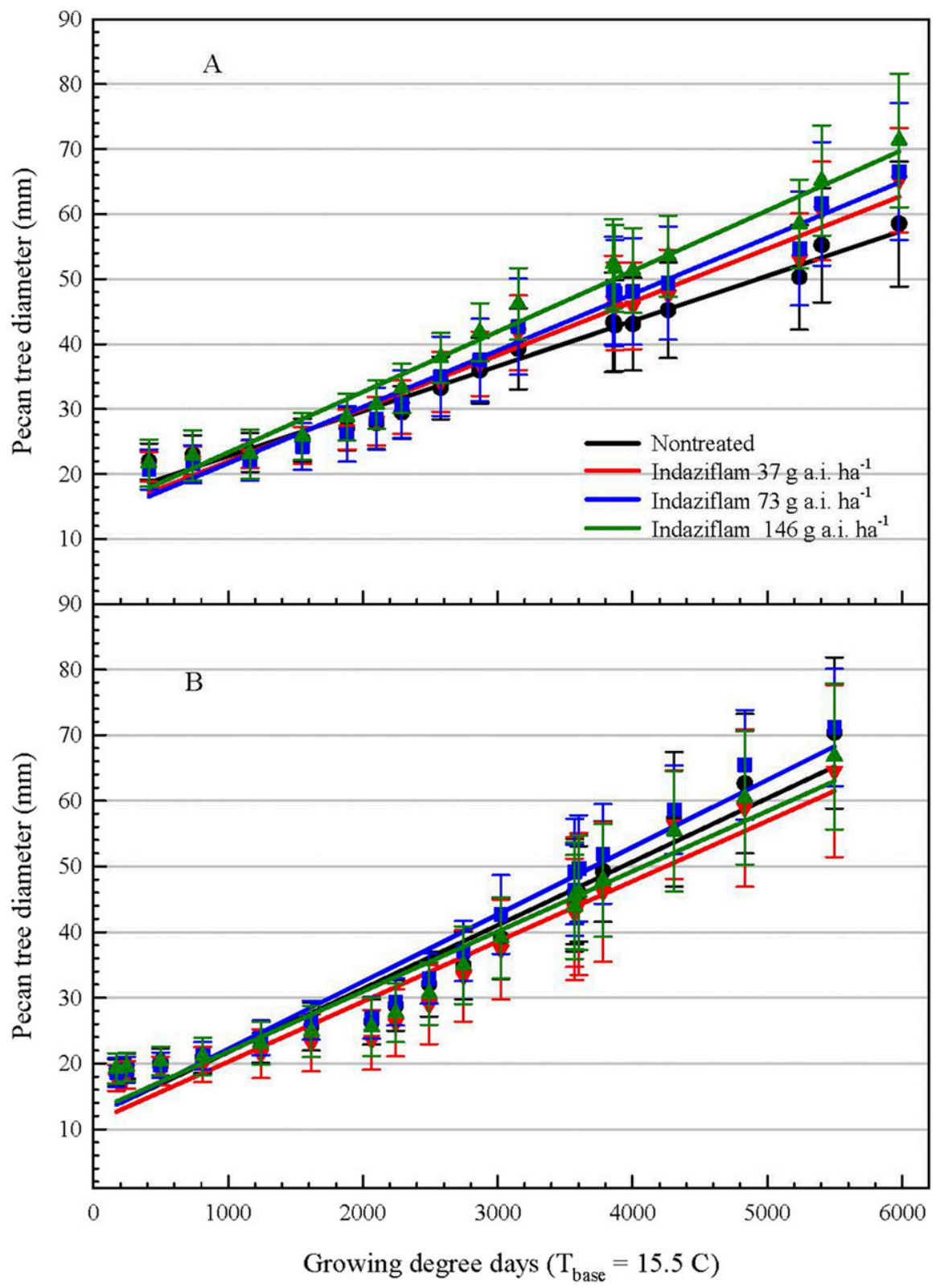

Fig. 2. Pecan tree growth response to multiple spring and autumn applications of indaziflam over growing degree days from 2012 to 2014 in Dougherty (A) and Webster Counties (B) in Georgia. Herbicide application dates are in Table 1 and parameter estimates for linear regression equations are in Table 5. 
decreased potential for mobility out of the rooting zone (Alonso et al., 2011). For this Georgia research, no trees died during the course of the 4 years of these experiments. As the soil $\mathrm{pHs}$ for these experiments were 6.0 6.5 , the solubility of indaziflam would have been $\approx 2.0 \mathrm{~g} \cdot \mathrm{L}^{-1}$ (Shaner, 2014). Jhala et al. (2012) noted that indaziflam leaching in a Chandler sand (Hyperthermic, uncoated Typic Quartzipsamments) was rate and rainfall dependent where 73 and $145 \mathrm{~g}$ a.i./ha leached to depths of $12.6,19.5$, and $23.4 \mathrm{~cm}$, and 18.2 , 23.3 , and $30.2 \mathrm{~cm}$ with 5,10 , and $15 \mathrm{~cm} \cdot \mathrm{ha}^{-1}$ of rainfall, respectively. For these studies in Faceville loamy sand and Greenville sandy clay loam soils, rainfall was sufficient after each application to leach indaziflam into pecan tree rooting zones, according to bioassay test performed by Jhala et al. (2012). For Dougherty County T1, T2, and T3, more than $3000 \mathrm{~mm}$ of rainfall was recorded, whereas Webster County T4 received more than $2400 \mathrm{~mm}$ in the 31 total months of these experiments (Tables 2 and 3 ).

There were no differences in tree trunk diameter data from 1 year of research for peach rootstock with almond scions in a California nursery (Abit and Hanson, 2013). According to the Alion ${ }^{\circledR}$ label registration, the recommended application rate is $51 \mathrm{~g}$ a.i./ha for a single application with a maximum of $102 \mathrm{~g}$ a.i./ha in a single growing season (Anonymous, 2015a). These data indicate that the newly planted pecan tree was tolerant to indaziflam and halosulfuron over time when only spring applications were applied. Pecan trees grew at a positive rate similar to other indaziflam-treated perennial crops including olive (Grey et al., 2016), conifers (Miller and Peachey, 2014), and woody ornamentals (Parker and Myers, 2011).

\section{Conclusions}

These data indicate that pecan trees planted in Georgia were tolerant of repeated applications of indaziflam and halosulfuron over time, offering herbicides that will provide extended weed control to maintain optimum growing conditions soon after planting. The safety of indaziflam in Georgia pecan was demonstrated as there were no visual injury symptoms or differences for pecan tree height for any treatment for any experiment taken in the first years of all four experiments. Alternative herbicides with different mechanisms of action should also be used in this production regime to prevent potential resistance issues.

\section{Literature Cited}

Abit, M.J. and B.D. Hanson. 2013. Evaluation of preemergence and POST-directed herbicides on rootstock safety in field-grown almond nursery stock. HortTechnology 23:462-467.

Allen, R. 2011. Alion: A new preemergent herbicide for the TNV market. Calif. Weed Sci. Soc. J. 7:4-5.
Alonso, D.A., W.C. Koskinen, R.S. de Oliveria, Jr., J. Constantin, and S. Mislankar. 2011. Sorptiondesorption of indaziflam in selected agricultural soils. J. Agr. Food Chem. 59:13069-13101.

Alonso, D.G., O.S. Rubem, K.E. Hall, W.C. Koskinen, C. Jamil, and M. Suresh. 2015. Changes in sorption of indaziflam and three transformation products in soil with aging. Geoderma 239-240:250-256.

Andales, A., J. Wang, T.W. Sammis, J.G. Mexal, L.J. Simmons, D.R. Miller, and V.P. Gutschick. 2006. A model of pecan tree growth for the management of pruning and irrigation. Agr. Water Mgt. 84:77-88.

Anonymous. 2015a. Alion herbicide specimen label. Bayer Crop Science. 21 July 2016. $<$ http://www.cdms.net/ldat/ldA75002.pdf $>$.

Anonymous. 2015b. Sandea ${ }^{\circledR}$ herbicide label. 25 Oct. 2015. <http://www.cdms.net/ldat/ld9I9004. pdf $>$.

Brabham, C., L. Lei, Y. Gu, M. Barrett, and S. DeBolt. 2014. Indaziflam herbicidal action: A potent cellulose biosynthesis inhibitor. Plant Physiol. 166:1177-1185.

Carpenter, A.C., S.A. Senseman, and H.T. Cralle. 1999. Adsorption-desorption of halosulfuron on selected Texas soils. Proc. South. Weed Sci. Soc. 52:211

Dermiyati, S.K. and I. Yamamoto. 1997a. Degradation of the herbicide halosulfuron in two soils under different environmental conditions. J. Pestic. Sci. 22:282-287.

Dermiyati, S.K. and I. Yamamoto. 1997b. Relationships between soil properties and sorption behavior of the herbicide halosulfuron in selected Japanese soils. J. Pestic. Sci. 22:288-292.

Dittmar, P.J., K.M. Jennings, J.R. Schultheis, and D.W. Monks. 2008. Effects of postemergence and postermergence-directed halosulfuron on triploid watermelon. Weed Technol. 22:467-471.

Faircloth, W.H., M.G. Patterson, W.G. Foshee, M.L. Nesbitt, and W.D. Goff. 2007. Comparison of preemergence and postemergence weed control systems in newly established pecan. Weed Technol. 21:972-976.

Flitcroft, I. 2015. Georgia automated environmental monitoring network. Univ. Georgia, Griffin, GA. 15 Nov. 2015. <http://www.georgiaweather.net>.

Glantz, S.A. and B.K. Slinker. 2001. Primer of applied regression and analysis of variance. 2nd ed., p. 25-28. McGraw-Hill, Medical Pub. Division, New York, NY.

González-Delgado, A.M. and M.K. Shukla. 2017. Effect of indaziflam application and soil manipulations on pecan evapotranspiration and gas exchange parameters. HortScience 52:910-915.

González-Delgado, A.M., J. Ashigh, M.K. Shukla, and R. Perkins. 2015. Mobility of indaziflam influenced by soil properties in a semi-arid area. PLoS One 10:E0126100.

Grey, T.L., K. Rucker, T.M. Webster, and X. Luo. 2016. High-density plantings of olive trees are tolerant to repeated applications of indaziflam. Weed Sci. 64:766-771.

Grey, T.L., A.S. Culpepper, and T.M. Webster. 2007a. Residual herbicide dissipation from soil covered with low-density polyethylene mulch or left bare. Weed Sci. 55:638-643.

Grey, T.L., A.S. Culpepper, and T.M. Webster. 2007b. Autumn vegetable response to herbicides spring applied under polyethylene mulch. Weed Technol. 21:496-500.

Haar, M.J., W.T. Lanini, C.E. Bell, S.S. Fennimore, and M.E. McGiffen. 2002. Evaluation of preemergence herbicides in vegetable crops. HortTechnology 12:65-99.

Jennings, K.M. 2010. Tolerance of fresh-market tomato, to postemergence-directed imazosulfuron, halosulfuron, and trifloxysulfuron. Weed Technol. 24:117-120.

Jhala, A.J., M. Singh, and A.M. Ramirez. 2012. Leaching of indaziflam applied at two rates under different rainfall situations in Florida Candler soil. Bul. Environ. Contam. Toxicol. 88:326-332.

Jhala, A.J., A.M. Ramirez, and M. Singh. 2013. Tank mixing saflufenacil, glufosinate, and indaziflam improved burndown and residual weed control. Weed Technol. 27:422-429.

Lee, R.D. 1994. Weed management in pecans. Coop. Ext. Service. Guide H-632. New Mexico State Univ.

McCullough, P.E., J. Yu, and D. de Barreda. 2013. Efficacy of preemergence herbicides for controlling dinitroaniline-resistant goosegrass in Georgia. Weed Technol. 27:639-644.

Miller, T. and E. Peachey. 2014. New and emerging herbicide tools for weed control in conifer nurseries. Natl. Proc. For. Conserv. Nurs. Assn. 2013. USDA For. Serv., Rocky Mountain Res. Sta. Proc. RMRS-P 72:57-61. 19 Feb. 2018. <http://www.fs.fed.us/rm/pubs/rmrs p072.html>.

National Agricultural Statistics Service (NASS). 2015. United States Department of Agriculture. 2 July 2015. <http://www.nass.usda.gov/ Statistics_by_Subject/index.php?sector=Crops $>$.

Parker, A. and D. Myers. 2011. Weed control and ornamental tolerance with indaziflam. Proc. South. Weed Sci. Soc. 64:103.

Perry, D.H., J.S. McElroy, M.C. Doroh, and R.H. Walker. 2011. Indaziflam utilization for control of problematic turfgrass weeds. Appl. Turf. Sci. doi:10.1094/ATS-2011-0428-01-RS.

SAS Institute Inc. 2012. SAS/STAT ${ }^{\circledR} 9.2$ User's Guide. SAS Institute Inc., Cary, NC.

Sikkema, S.R., D.E. Robinson, P.H. Sikkema, and N. Soltani. 2008. Response of sweet maize hybrids to halosulfuron. Crop Protection 27 . 695-699.

Shaner, D.L. 2014. Herbicide handbook. 10th ed., p. 266-267. Weed Sci. Soc. Amer., Champaign, IL.

Smith, M.W. 2011. Pecan production increased by larger vegetation-free area surrounding the tree. Scientia Hort. 130:211-213.

United States EPA. 2010. Pesticide fact sheet: Indaziflam. Conditional registration. 21 July 2016. <https://www3.epa.gov/pesticides/chem search/reg_actions/registration/fs_PC-080818_ 26-Jul-10.pdf>.

Webster, T.M., A.S. Culpepper, and W.C. Johnson, III. 2003. Response of squash and cucumber cultivars to halosulfuron. Weed Technol. 17: 173-176.

Wells, L. 2015. Irrigation water management for pecans in humid climates. HortScience 50: 1070-1074.

Wells, L. 2014. Pecan planting trends in Georgia. HortTechnology 24:475-479.

Wolfe, K. and K. Stubbs. 2016. 2015 Georgia farm gate Value report. AR-16-01. 5 Oct. 2017. <http:// www.caes.uga.edu/center/caed/>.

Zheng, W., S.K. Papiernik, and S.R. Yates. 2008. Transformation kinetics and mechanism of the sulfonylurea herbicides pyrazosulfuron and halosulfuron in aqueous solutions. J. Agr. Food Chem. 56:7367-7372. 